\title{
Returnable packaging as a sustainability factor in the automotive chain: a case study.
}

\author{
Getulio K. Akabane \\ CPS-Centro Paula Souza Master Program-São Paulo-Brazil \\ Fernando José Bussola \\ CPS-Centro Paula Souza Master Program-São Paulo-Brazil \\ Antonio César Galhardi \\ CPS-Centro Paula Souza Master Program-São Paulo-Brazil \\ Hamilton Pozo \\ Faculty of Technology "Rubens Lara”- Santos- Brazil \\ José Martino Neto \\ Faculty of Technology Guarulhos- Guarulhos- Brazil
}

\begin{abstract}
Packaging makes a valuable contribution to economic, environmental and social sustainability through product protection, waste prevention, enabling efficient business conduct and providing consumers with the benefits of the products it contains. The case study chosen for the work was carried out in a multinational automotive company with the objective of researching the financial and environmental factors in the substitution of one-way packages by the returnable ones during the distribution of parts for automotive dealers. There is no single solution to manage packaging waste. The best combination of options depends on local conditions, especially demographics and the degree of investment made in modern processing systems. Determining the best combination of options for managing packaging waste therefore requires detailed case-by-case analysis where life-cycle assessments can provide valuable decision support.
\end{abstract}

Key-words: Packaging, sustainability, waste, finances

\section{INTRODUCTION}

Packaging is one of the important issues in allocating resources in different industrial sectors, especially in manufacturing and logistics services. Without packaging, food deteriorates, fragile products are damaged and the dispensing process becomes harmful and the entire supply chain becomes extremely inefficient.

The pressure on packaging is not a new phenomenon, but has increased dramatically in the 21st century by the perceptions of media-driven consumers and legislation that demand increasingly "sustainable" packaging, making it a major challenge for businesses.

Packaging came to be perceived as an autonomous product, thus transcending its fundamental role, which is to protect, distribute and display goods.

While essential, packaging is rarely analyzed deeply, and the sociocultural pressure that the market imposes for packaging to be "sustainable" is confronted with a lack of common understanding of what it can mean. 
As a result, companies end up having to deal with conflicting demands from consumers, regulators and other stakeholders. This requires time, a significant cost, and a source of friction between the companies and the communities in which they operate.

Wu et al. (2016) emphasize that packaging has a number of functions and its fundamental role is to deliver the product to the consumer in perfect condition. Good packaging uses only the right kind of material needed to accomplish this task, but excessive reductions in its cost make the economy false because as the packaging is reduced, the range of scenarios under which the frequency of product losses increases until the destination point is reached, where the loss of the product exceeds the savings in the packaging material.

Transport packaging (or tertiary packaging) is intended to ensure handling and transport without damage to a given operation, whether by road, rail, waterway or air.

With the entry of numerous automakers in the Brazilian market, and due to the high competitiveness of the automotive sector, obtaining a competitive advantage through the improvement of logistics processes has become a determining factor for the company's survival and success. Reducing costs and minimizing the environmental impact of packaging is a key element in business operations in today's world.

The case study chosen for the work was carried out in a multinational automotive company, where its headquarters are in the city of São Paulo and it has a relationship with dealers throughout the country. The research encompasses one of the actions of the company aiming at the sustainability aspect regarding the reduction of economic and environmental costs in the study of the substitution of disposable boxes by returnable ones in the supply of parts for the concessionaires.

In this way, the objective is to investigate the financial and environmental factors in the substitution of one-way packages for the returnable ones during the distribution of parts for automotive dealers.

\section{Corporate sustainability}

\section{LITERATURE REVIEW}

In 1987 at the World Commission on Environment and Development under the leadership of the former Norwegian Prime Minister Brundtland, he presented the definition of Sustainable Development as "a development capable of meeting the current needs of an intact environment, social justice and economic prosperity without limit the ability of future generations to meet their needs, where preservation of the natural environment is a prerequisite for a functioning economy and social justice. " (FINKBEINER, 2010).

For Kuhlman and Farrington (2010) there has always been the counterpoint in the relationship between humanity and nature, where one view reinforces that nature must be conquered and the other emphasizes a relationship of adaptation and harmony. Although the first view has been prevalent in recent centuries, the second has become a constant questioning in behavior since the 1970s.

Philippi Jr et al. (2017) stand out from the current decade and increasingly on the environmental issue, on the one hand, it needs to meet the legal and environmental requirements of specific markets, and the other that strengthens a consumer market that prefers companies with ecological-environmental characteristics. In this context, a new reality 
arises where elements previously less related to the survival of the company are important and are closely linked to their economic and financial health. With this, it becomes essential to incorporate the socio-environmental theme in the organizational decision-making processes.

In discussing sustainability in a business context, the concept of the Triple Bottom Line (TBL or 3BL), which represents the sustainability tripod that encompasses the social, environmental and economic requirements of productive activities, is essential for full understanding. an integrated form, reflecting a balance in terms of result between the three Ps: People, Profit and Planet (Elkington, 1997).

In fact, these three pillars are closely linked and cannot be developed in isolation. They came to be recognized as the standard approach to consider sustainability according to the British Standards Organization (2006).

- People - Social equity and cohesion: "Promoting a democratic, socially inclusive, cohesive, healthy, secure and fair society with respect for fundamental rights and cultural diversity that creates equal opportunities and combats discrimination in all its forms."

- Profit - economic prosperity: "Promote a thriving, innovative, knowledge-rich, competitive and eco-efficient economy that offers high standards of living and full, highquality employment across the globe."

- Planet - Environmental protection: "Protect the earth's capacity to support life in all its diversity, respect the limits of the natural resources of the planet and ensure a high level of protection and improvement of the quality of the environment. environmental and promote sustainable consumption and production to break the link between economic growth and environmental degradation. "

When practical examples of the three pillars are provided, environmental aspects, including climate change, resource use and biodiversity tend to predominate, followed by social aspects of public health and work protection.

The economic imperative to maintain the standard of living keeps all three aspects in balance. The challenge is to work holistically with these three pillars, recognizing the tensions between them and respecting the importance of each. A brief definition encapsulating this is "sustainable development: a lasting and balanced response to economic activity, environmental responsibility and social progress" (BRITISH STANDARDS ORGANIZATION, 2006).

Companies have been adapting their business models and including products, services and processes based on the sustainability tripod, assuring to their stakeholders tangible, economic and financial and intangible returns, such as credibility, knowledge, image, intellectual capital, driving the New Economy (PEREIRA, 2012).

Seeing an alternative that can contribute to the sustainable vision in the company, a perennial issue in many of them is in relation to product packaging.

Packaging makes a valuable contribution to economic, environmental and social sustainability through product protection, waste prevention, enabling efficient business conduct and providing consumers with the benefits of the products it contains.

Faria and Costa (2005) highlight two types of packages: one-way packaging where it is normally used only once and then discarded and returnable, which can be used several times. Like other logistics processes, the decision regarding the best type of packaging for the process 
should take into account the requirements of Integrated Logistics, where the main paradigm is to meet the level of service required by the customer at the lowest possible cost.

Leite (2003) makes a comparison between disposable and returnable packaging. Both returnable and disposable packages have direct shipping costs, return shipping, flow management, receipt, cleaning, occasional repairs, storage and invested capital. However, returnable packaging has other benefits such as environmental, greater protection of products and end of life, in many cases packaging can be returned to the manufacturer as recycled material and can be used in new packaging.

\section{ROLE OF PACKAGING IN SUSTAINABILITY}

The contribution of packaging to economic, environmental and social sustainability can be illustrated by the fact that, in developing countries, the lack of packaging or inadequate packaging in distribution causes 30 to 50 percent of all food to disintegrate before to reach the consumer (WORLD HEALTH ORGANIZATION, 1984, MADI, 1984). In Western Europe, where food is packaged efficiently, only $2 \%$ to $3 \%$ of the food produced does not reach the consumer (PRO-EUROPE, 2004).

The products generally represent more resources and have an inherent value greater than the packaging used to protect them (Kooijman, 1994, Erlöv et al., 2000, Busser et al., 2008). Thus, losses of products due to low performance packaging are likely to cause much greater adverse effects on the environment than the gains obtained through excessive packaging reduction (KOOIJMAN, 1994, ERLÖV et al, 2000, BUSSER et al, 2008 , INCPEN, 1995).

If, in developing countries, average losses in the food supply chain could be reduced by using improved packaging of $40 \%$ for the European average of $2.5 \%$, the energy consumption associated with food losses would be reduced by more than $50 \%$, also increasing the availability of food.

Improvements in the environmental performance of the packaging should not be generated to generate major negative environmental impacts elsewhere in the product life cycle and should only be continued if the impacts of the packaged product are maintained or reduced.

There are several initiatives to improve the system of packaged products and encourage improvements that contribute to product sustainability, including:

- The European Parliament and Council (1994), which defines legal requirements for the packaging of EU participants, actions for the reduction, recycling, reuse and / or recovery of the source.

- The Conseil National de l'Emballage (2008) in France, which is committed to offering products to consumers at a minimal environmental and economic cost.

- UK INCPEN (1995) in its INCPEN5 report "Reducing Packaging: Doing More with Less" describes actions such as reduction of sources, selection of materials and improved packaging compatibility with existing recycling and recovery schemes.

Such strategies and efforts are means to optimize the total system of packaged products and does not end in themselves. 


\section{REUSE, RECOVERY AND DISPOSAL}

A central objective of the EU Waste Framework Directive is to prevent and reduce waste generation (CEN, 2003). Since packaging avoids wastage of products, it is contributing significantly to this goal.

The reuse of packaging (CEN, 2003,2004) under Article 5 of the Packaging Waste Directive means that it is returned to the factory and reloaded. It must support several rotations of this type within its life cycle before being recovered when it can no longer be used. There is no general preference for reusable or non-reusable packaging, the choice depends entirely on the local supply chain and the market.

We should also highlight that recycling can play a key role in the product life cycle, through the energetic economy, can provide its decrease in the manufacturing process, such as:

- Aluminum recycling saves up to 95\% of the energy required for virgin materials (ENERGY INFORMATION ADMINISTRATION, 2006),

- Recycling of PET9 saves about 50\% of energy (FEDERAL OFFICE OF THE ENVIRONMENT, 2007).

The organization Eco Emballages (2007) emphasizes that the application of recycling should be adopted, where it results in lower environmental impacts than other recovery alternatives and that meet other requirements such as safety.

Some types of recovered material are also a valuable source of energy (incineration with energy recovery). Therefore, recycling needs to be considered within a balanced approach to packaging recovery.

The ideal balance between recycling and energy recovery varies greatly with the waste composition.

\section{Overview of the automotive industry in Brazil}

The automotive sector is a major driver of the national and global economy and fosters innovation to a large extent due to the high competitiveness of the industry and its strong participation in general trade.

In Brazil, according to ANFAVEA (2017b), the automotive sector is present in all Brazilian regions with 67 industrial units and currently employs more than 121 thousand direct employees and approximately 1.3 million jobs throughout the production chain. For 2017, a national production of 2.2 million vehicles was estimated, with a growth prospect for the coming years, as shown in Chart 1. 


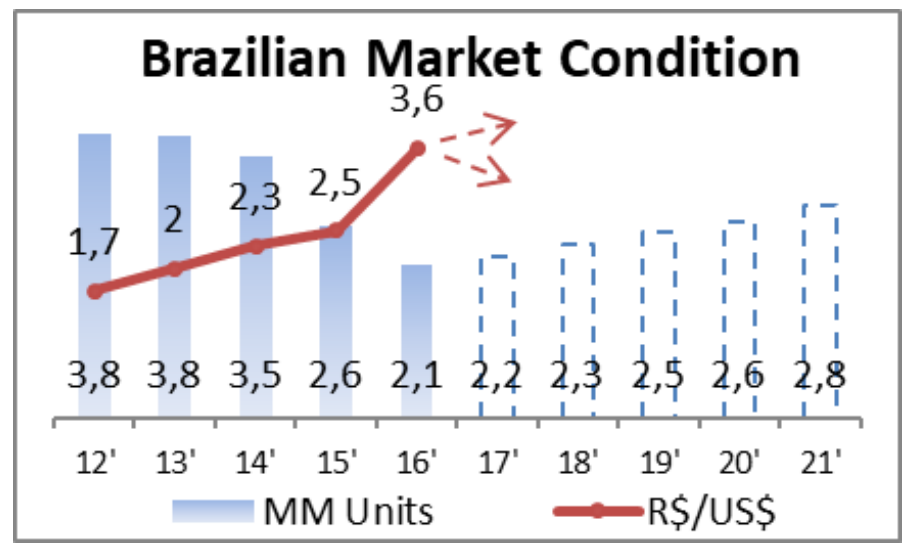

Source: Site of ANFAVEA (2017a).

The automotive sector is considered one of the pillars of support for the economy and trade of parents. Its structure influences whole cities where it is installed, due to its potentiality and strength (VAZ ET AL., 2017).

Di Serio (2007) describes that the development of the automobile chain in Brazil began with the installation of the first Ford assembly unit in 1919, followed by GM in 1925. During this period the two companies imported dismantled kits and parts from other countries and mounted in their lines located in São Paulo to comply with local legislation. In the 1950s, with the public policies of economic and industrial development of the government of Vargas (19511954) and later Kubitschek (1956), culminated with the factory facilities of the GM, VW and Ford companies in the country with the traditional model of mass production.

According to Neto and Pires (2007), the automotive sector expands its structures worldwide, within this continuous process, Brazil currently finds itself as a participant in ERMs (Emerging Regional Markets) along with Argentina, Russia and Turkey. The Brazilian market is attractive because it has a fast growth of the vehicle market, production units in locations with lower costs, accelerated growth of motorization rates, characteristics common to the country classified in ERMs. In the automobile chain in Brazil, several organizational arrangements were also implemented, including the modular consortium and industrial condominium.

As in all segments, the search for improvements in processes, products, as well as creating competitive advantages should not be separated from sustainability concerns.

\section{RESEARCH METHODOLOGY}

It is a case study of a qualitative nature, which emphasizes the perspective of the individual being studied, so that it is possible to obtain information from these perspectives, to interpret the environment in which the problem is found (CAUCHICK. Therefore, the natural environment in which individuals are inserted becomes the research environment. The method to be employed is the single case study, which has as object of study a leading automotive multinational in its segment, which will be called ABC.

For Yin (2001), a case study is: "an empirical investigation of a contemporary phenomenon within its real-life context, and when the boundaries between phenomenon and context are not clearly defined." According to Eisenhardt (1989) the case study can be used to provide a 
description; test a theory; or generate a new theory. For Bryman (1989), the primary concerns of this approach are: measurability; causality; generalization; replication.

For this study, the sources of internal evidence (YIN, 2001) were considered, such as interviews with those responsible for the logistics sector of the company ABC, complemented with the technique of direct observation in the parts and accessories distribution center of the referenced company.

The selected sample can be considered as a convenience, which is characterized as nonprobabilistic, in which the researcher selects more accessible members of the population, aiming at collecting data and information in a more simplified way. Respondents were selected as: managers and managers of certain sectors of the company (AAKER; KUMAR; DAY, 1995).

The treatment of the data was statistical that seeks to describe the characteristics of a given situation, measuring numerically the objective raised about a research problem.

\section{Outbound logistics}

\section{PRESENTATION AND ANALYSIS OF RESULTS}

Distribution logistics or outbound logistics is associated with the movement of material from a point of production or storage to the customer, and also including the return of the goods in good or bad condition as part of this process (BERTAGLIA, 2009).

The distribution of spare parts in Brazil was segmented according to Figure 1 below into 5 major regions, according to the delivery points served by 5 carriers.

Figure 1 - Brazil Map divided by service regions

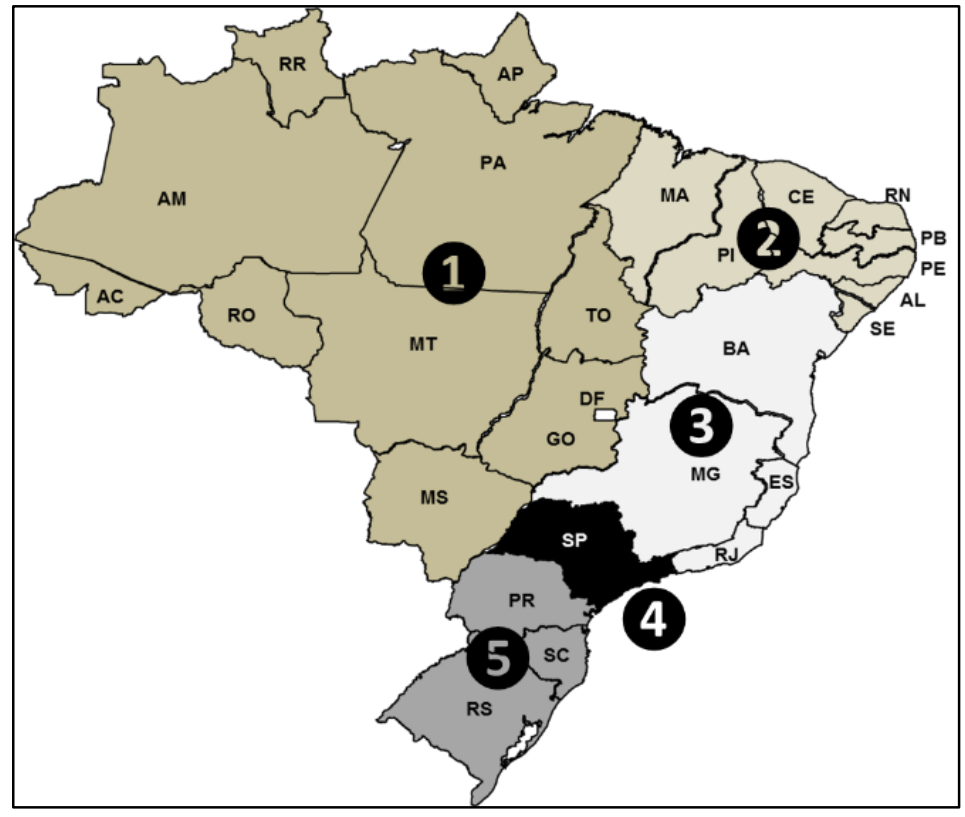

Source: Prepared by the authors

\section{CURRENT SITUATION}

The distribution of spare parts in Brazil was segmented into regions identified from 1 to 5 by the company, according to the delivery points attended by five carriers. 
Due to the great extent of the Brazilian territory, the XPTO company delimits 60 objects delivery points studied in this research: Region 3 that includes Rio de Janeiro (7 dealers) and Minas Gerais (9 dealers); Region 4 that encompasses São Paulo (44 dealers).

For this study only the two one-way packaging models were considered, with the highest volume of consumption, the packages denominated in this study as "A" and "B". As figure 2 indicates: first the volume and flow for the packages based on the current situation, with all volumes of small parts being shipped daily in carton boxes.

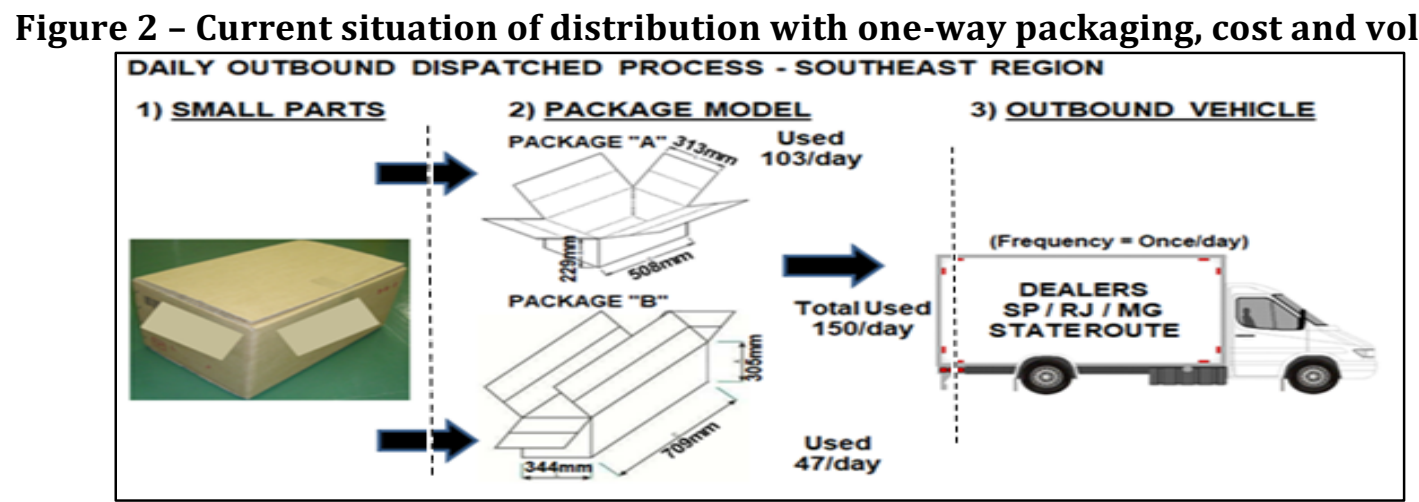

Source: the author, 2017.

Considering the 240 days of dispatch per year and the respective acquisition costs of each model, figure 3 shows a summary of the volumes and values involved in the operation with one-way carton boxes.

Figura 3 - Current situation cost and volume

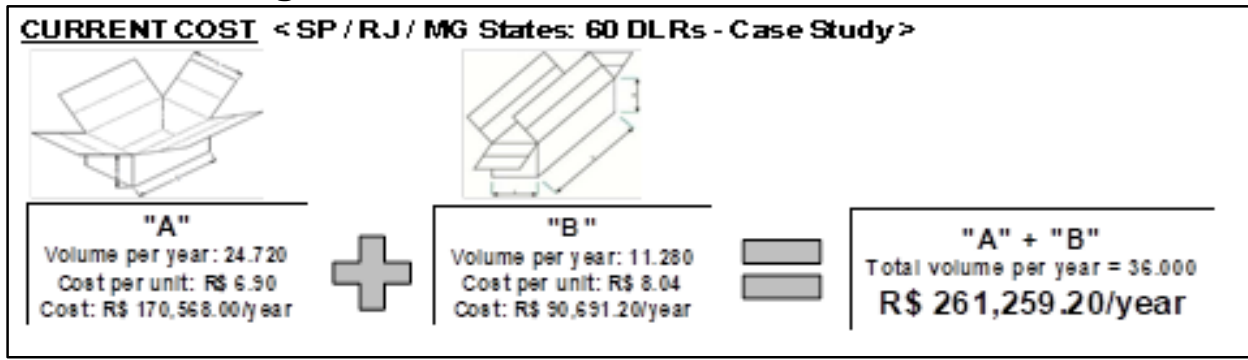

Source: the author, 2017.

\section{Proposed situation}

Figure 4 demonstrates the new flow, as well, as the new volume involved in the proposal to replace the two types of "A" and "B" carton boxes with only one returnable plastic box model called " $\mathrm{C}$ ", being this box with a volume and sufficient occupation to replace the previous two models. 
Figure 4 - Proposed distribution situation with returnable packaging.

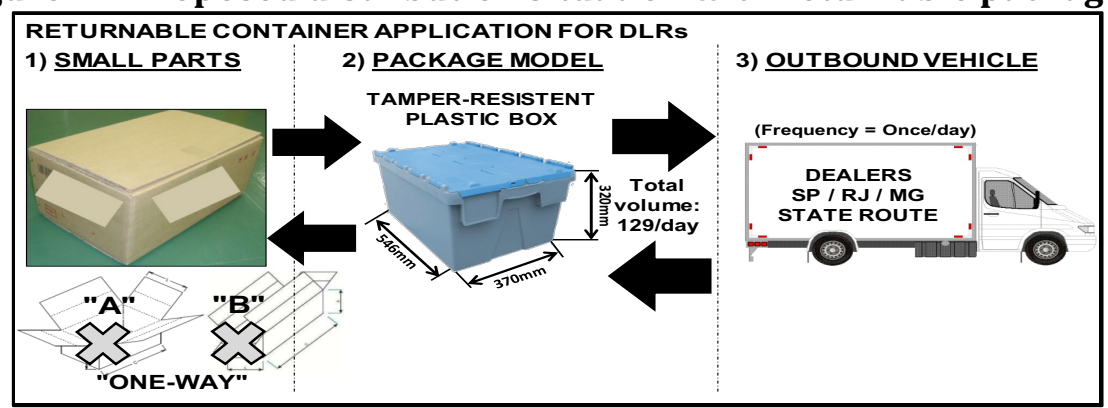

Source: as per the author, 2017.

Considering the same 240 days of dispatch per year, the cost of acquiring the new model, the cost of reverse logistics and replacement cost of any damaged and / or lost boxes, the final cost comparing with the current situation, is demonstrated as per figure 5 below.

\begin{tabular}{|c|c|c|}
\hline $\begin{array}{l}1 \text { CURRENT SITUATION } \\
\text { <"A" + "B" ONE-WAY> } \\
\text { TOTAL COST/YEAR } \\
\end{array}$ & $\begin{array}{l}2 \text { PROPOSAL SITUATION } \\
\text { <"C" RETURNABLE> } \\
\text { TOTAL COST/YEAR } \\
\end{array}$ & $\begin{array}{l}\text { COST COMPARISON } \\
\text { CURRENT } \times \text { PROPOSAL }\end{array}$ \\
\hline $\begin{array}{l}\text { Total volume \& cost / year: } \\
\text { "A": } 24.720 \text { units \& } R \$ 170,568.00 \\
\text { "B": } 11.280 \text { units \& } R \$ 90,691.20 \\
\text { TOTAL cost / year : } \\
\text { R\$ } 261,259.20\end{array}$ & $\begin{array}{l}\text { Total volume / day: } 871 \text { (Round Trip + Inventory) } \\
\text { (a) Box acquistion cost / year: } R \$ 66,892.20 \\
\text { (b) Box replacement (5\%): } R \$ 3,388,00 \\
\text { (c) Logistics impact (reverse): } R \$ 83,390.40 \\
\text { TOTAL cost / year: (a) + (b) + (c) } \\
R \$ 153,670.60\end{array}$ & $\begin{array}{l}\text { (1ONE-WAY: R\$ 261,259.20 } \\
\text { 2RETURNABLE: R\$ 153,670.60 } \\
\text { Cost reduction (2) - (1): } \\
\text { - R } \$ 107,588.60 \\
\downarrow 41.18 \%\end{array}$ \\
\hline
\end{tabular}

Source: the author, 2017.

As per the comparative table in figure 5, a gain of $\mathrm{R} \$ 107,588.60$ per year is demonstrated, using the returnable plastic box instead of carton boxes, which also means a reduction of $41.18 \%$ compared to the current annual cost, already discounting the initial investment shown in column 2.

It is possible to calculate the financial gains for the next 5 years, as per the results presented in figure 5. Considering that the initial investment is discounted already in the first year, and the gain in this same period is in $\mathrm{R} \$ 107,588.60$.

For the next 4 years, the initial investment amount will not be discounted, as: (b) box replacement cost: $\mathrm{R} \$ 3,388.00$, and (c) logistics impact (reverse) R \$ 83,390.40. Therefore, there will be: the total value of one-way cartons (a) 261,259.20 - (b) box replacement cost $R$ \$ $3,388.00$ - (c) logistics impact (reverse) R \$ 83,390.40 = R \$ 174,480.80 gain for the second, third, fourth and fifth following years.

Table 1 - Annual consumption reduction of cardboard in kilograms (kg).

\begin{tabular}{cccc|}
\hline Box type & Volume/year & Unit weight & Total weight \\
\hline "A" & 24,720 & 1 & 24,720 \\
"B" & 11,280 & 1 & 11,280 \\
\hline & & TOTAL: & 36,000 \\
\hline
\end{tabular}

Source: the author, 2017.

\section{CONCLUSIONS / FINAL CONSIDERATIONS}

Due to the high competitiveness of the Brazilian automotive sector, the process of continuous improvement in the reverse logistics chain has become a crucial factor for the success of the companies. 
The sustainability factor has been considered as a fundamental element in operations, where its adequate application can add values in the companies' results.

In this way, it can be observed, based on the results presented in this study, the existence of a gain in the first year of $\mathrm{R} \$ 107,588.69$, equivalent to $41.18 \%$ of cost reduction and also, an environmental economy of consumption of 36 tons of cardboard per year with the replacement of the one-way packaging by the returnable ones, resulting in significant financial and environmental gains.

It is possible to confirm the contribution of the returnable packaging strategy as an important procedure in the viability of the sustainable action in the business logistic processes.

On the other hand, the results obtained in this research also showed the financial feasibility of replacing one-way packages with returnable items without compromising the quality of the parts distribution processes for automotive dealers, and it is possible to significantly reduce the consumption of in this process.

In addition, the study was limited to only two types of packages, called "A" and "B" and in a specific logistic flow of spare parts distribution in Regions 3 and 4. However, it is necessary to extend the present research for all five regions, integrating the supply chain at the national level, in order to identify new opportunities for improvements and gains in the substitution of one-way packages for returnable ones.

There is no single solution to manage packaging waste. The best combination of options depends on local conditions, especially demographics and the degree of investment made in modern processing systems. Determining the best combination of options for managing packaging waste therefore requires detailed case-by-case analysis where life-cycle assessments can provide valuable decision support.

It was noted in this way that the expansion of the strategy to other logistics sectors and other operations could lead to other economies and thus add new values to the company's processes in its global scope.

\section{References}

Aaker, D. A., Kumar, V., \& Day, G. S. (1995). Marketing research. John Wiley \& Sons.

ANFAVEA (2017a). Dados Estatísticos. Recuperado em 08 setembro, 2017, de:< http://www.anfavea.com.br/estatisticas.html>.

ANFAVEA (2017b). Anuário das Indústrias Automobilísticas Brasileiras. Recuperado em 06 setembro, 2017, de:< http://www.anfavea.com.br/anuarios.html>.

Bertaglia, P.R. (2009). Logística e Gerenciamento da Cadeia de Suprimentos. São Paulo: Saraiva.

British Standards Organisation (2006). BS 8900 - Guidance for Managing Sustainable Development. London: British Standards Organisation - Recuperado em 30 agosto, 2017, de:< http://www.bsi-global.com/Shop>.

Bryman, A. (1989). Research methods and organization studies. London \& New York: Routledge.

Cauchick, P.A \& Martins, R.A. (212) Metodologia de pesquisa para engenharia de produção e gestão de operações. Rio de Janeiro: Elsevier.

CEN (2003). EN-13437:2003 Packaging and material recycling - Criteria for recycling methods - Description of recycling processes and flow chart. Recuperado em 15 setembro, 2017, de http://www.cen.eu/cenorm/index.htm. 
CEN (2004). EN 13429:2004 Packaging - Reuse. Recuperado em 15 setembro, 2017, de http://www.cen.eu/cenorm/index.htm.

Di Serio, L. C., Sampaio, M., \& Farias Pereira, S. C. (2007). A evolução dos conceitos de logística: um estudo na cadeia automobilística no Brasil. RAI-Revista de Administração e Inovação, 4(1).

Conseil National de l'Emballage - French Packaging Council (2008). Taking Account of the Environmental Requirements in the Design and Manufacture of Packaging in France. Recuperado em 15 setembro, 2017, de $\mathrm{http}$ ///www.conseil-emballage.org/taking-into-account-environmental-requirements-in-the-design-andmanufacture-of-packaging/?lang=en

Eco Emballages (2007). Resource Saving from Recycling. Levallois-Perret (France): Eco Emballages. Recuperado em 15 agosto, 2017, de: <http://www.ecoemballages.fr/le-tri-des-emballages/du-recyclage-au-recycle/>.

Elkington, J. (1997) Cannibals with forks: the triple bottom line of 21st century business. Oxford: Capstone.

Energy Information Administration (2006). Recycling Aluminium. Washington D.C.: Energy Information Administration (USA). Recuperado em 15 setembro, 2017, de http://www.eia.doe.gov/kids/energyfacts/saving/recycling/solidwaste/metals.html.

Erlöv, L., Löfgren, C., \& Sörås, A. (2000). Packaging: A tool for the prevention of environmental impact. Packforsk. European Parliament and Council . (1994). Directive 94/62/EC. Recuperado em 19 setembro, 2017, http://eurlex.europa.eu/legal-content/EN/TXT/PDF/?uri=CELEX:31994L0062\&from=EN

Faria, A. C. \& Costa, M. F. G. Gestão de Custos Logísticos. São Paulo: Atlas, 2005.

Federal Office of the Environment (2007). PET Recycling. Bern: Federal Office of the Environment Switzerland). Recuperado em 01 setembro, 2017, de:

<http://www.bafu.admin.ch/abfall/01495/01498/01503/index.html?lang=en\#sprungmarke3_14>.

Finkbeiner, M., Schau, E. M., Lehmann, A., \& Traverso, M. (2010). Towards life cycle sustainability assessment. Sustainability, 2(10), 3309-3322.

INCPEN (1995). Packaging Reduction - Doing More With Less. Recuperado em 10 setembro, 2017, de https://www.linpacpackaging.com/files/packreduction.pdf

Kuhlman, T., \& Farrington, J. (2010). What is sustainability?. Sustainability, 2(11), 3436-3448.

Leite, P. (2003). Logística Reversa: Meio ambiente e competitividade. São Paulo: Prentice Hall.

Pereira, A.C.; Da Silva, G.Z. \& Carbonari, M.E. (2012). Sustentabilidade, responsabilidade social e meio ambiente. Editora Saraiva.

Philippi JR, A.; SAMPAIO, C.A.C. \& FERNANDES, V. (2017). Gestão Empresarial e Sustentabilidade. Barueri, SP: Manole.

Kooijman, J. M. (1994). Environmental assessment of food packaging: impact and improvement. Packaging technology and science, 7(3), 111-121.

Madi, L. F. (1984). The Importance of Packaging in the Distribution of Fresh Fruits and Vegetables in Latin America. Institute of food technology.

Neto, M. S., \& Píres, S. R. I. (2007). Organização da produção, desempenho e inovações na cadeia de suprimentos da indústria automobilística brasileira. Revista de Ciências da Administração, 9(19), 34.

S. Busser, R. Steiner \& N. Jungbluth. (2008). LCA of Packed Food Products. Brussels: ESU Services Ltd. for Flexible Packaging Europe.

Vaz, C. R., Rauen, T. R. S., \& Lezana, Á. G. R. (2017). Sustainability and Innovation in the Automotive Sector: A Structured Content Analysis. Sustainability, 9(6), 880.

Wu, H., Leung, S. C., Si, Y. W., Zhang, D., \& Lin, A. (2017). Three-stage heuristic algorithm for three-dimensional irregular packing problem. Applied Mathematical Modelling, 41, 431-444.

Yin, R.K. (2001). Estudo de caso: planejamento e métodos. Porto Alegre: Bookman.

World Health Organization (1984). Nutrition: Facts and Hope. Geneva: World Health Organization. 